\title{
A Case of Primary Diffuse Leptomeningeal Gliomatosis Predominantly Involving the Cervical Spinal Cord and Mimicking Chronic Meningitis
}

\author{
Kronik Menenjiti Taklit Eden Üst Servikal Primer Diffüz \\ Leptomeningial Gliomatozis
}

\author{
Dilara SAVCI HEIJINK ${ }^{2}$, Kamran URGUN ${ }^{1}$, Aydin SAV ${ }^{3}$, Askin SEKER ${ }^{1}$, Deniz KONYA ${ }^{1}$ \\ ${ }_{1}^{1}$ Marmara University, Faculty of Medicine, Department of Neurosurgery, Istanbul, Turkey \\ ${ }_{2}^{2}$ Marmara University Institute of Neurological Sciences, Laboratory of Neuropathology, Istanbul, Turkey \\ ${ }^{3}$ Marmara University, Faculty of Medicine, Department of Pathology, Istanbul, Turkey
}

Correspondence address: Deniz KONYA / E-mail: drkonya@hotmail.com

\begin{abstract}
Gliomas may rarely arise in the leptomeninges without any evidence of intraaxial involvement. A case of primary diffuse leptomeningeal gliomatosis (PDLG) histologically diagnosed as oligoastrocytoma is presented. A 50-year-old woman presented with nausea, vomiting and headache. Magnetic resonance imaging (MRI) of cranium and cervical region revealed dural thickening starting from the craniocervical junction to the level of C4 without any parenchymal lesions. CSF examination showed an increase in protein and decrease in glucose levels. There were neither any kind of atypical cells nor any kind of growth in bacterial cultures. The patient underwent biopsy at the level of C1 for diagnosis. The specimen was diagnosed as primary diffuse leptomeningeal gliomatosis, with phenotypic features of astrocytoma and oligodendroglioma.
\end{abstract}

KEYWORDS: Glial tumor, Meningitis, Primary diffuse leptomeningeal gliomatosis

öz

Gliomaların her hangi parenkimal bir yerleşim göstermeksizin primer olarak leptomeningeal tutulum ile ortaya çıkmaları son derece nadirdir. Histolojik olarak oligoastrositom tanısı konulan bir primer diffüz leptomeningeal gliomatozis olgusu sunulmaktadır. Elli yaşındaki bayan hasta bulantı, kusma ve baş ağrısı şikayetleri ile başvurmuştur. Kranial ve servikal manyetik rezonans (MR) görüntüleme incelemeleri kranioservikal bileşkeden başlayarak C4 seviyesine kadar her hangi bir parenkim tutulumu olmaksızın dura kalınlaşması ile uyumlu görünüm ortaya koymuştur. Beyin omurilik sıvısı (BOS) incelemelerinde her hangi bir atipik hücre saptanmamış olmakla birlikte protein seviyesinde artış, glukoz seviyesinde ise azalma saptanmıştır. Hastaya C1 seviyesinden tanısal amaçlı biyopsi yapılmıştır. Biyopsi materyaline fenotipik olarak astrositom ve oligodendrogliom özellikleri de içeren primer diffüz leptomeningeal gliomatozis tanısı konulmuştur.

ANAHTAR SÖZCÜKLER: Glial tümör, Menenjit, Primer diffüz leptomeningeal gliomatozis

\section{INTRODUCTION}

Gliomas may arise primarily in the leptomeninges without any evidence of intraaxial involvement $(1,12,14)$. This extremely rare and rapidly progressive condition, which is called primary diffuse leptomeningeal gliomatosis, is thought to originate from heterotrophic neuroglial nests in the subarachnoid spaces $(3,13)$. Clinical presentation has a broad spectrum of signs and symptoms mostly due to increased intracranial pressure. Symptoms and signs of the disease on admission may be similar to that of chronic infectious meningitis ( 7 , $14,18)$.

We report a case of a primary diffuse leptomeningeal oligoastrocytoma predominantly involving the cervical spinal cord and initially suggesting tuberculosis meningitis.

\section{CASE REPORT}

A 50-year-old, previously healthy female patient had complaints of nausea, vomiting and headache of approximately one month. Physical examination revealed bilateral papilledema with bilateral abducens nerve paralysis. Cranial magnetic resonance imaging (MRI) revealed no other abnormality including hydrocephalus except cystic masses $20 \times 15 \times 13 \mathrm{~mm}$ in diameter located bilaterally in the cerebellopontine angles (Figure $1 A, B$ ). These cystic masses were isointense with cerebrospinal fluid (CSF) on T1weighted images and hyperintense on T2-weighted images. The presence of an epidermoid cyst was ruled out as the lesions were hypointense on diffusion MRI. Lumbar puncture was performed, and CSF opening pressure was $600 \mathrm{mmH}_{2} 0$ (Normal $<180-200 \mathrm{mmH}_{2} \mathrm{O}$ ). Biochemical analysis of the CSF 
revealed an increase in protein $(189 \mathrm{mg} / \mathrm{dl}$; normal:15-45mg/ dl) level. Glucose level was slightly under the normal range (35mg/dl; normal: 40-80mg/dl). CSF/plasma glucose ratio was 25\% (Normal: 50\%). The cytological evaluation results of the CSF sample were normal. No growth was detected in any of the bacterial cultures.

The patient was started on oral methylprednisolone $(80 \mathrm{mg}$ TID) to lower the CSF-pressure. A ventriculoperitoneal (VP) shunt was inserted due to hydrocephalus three days after the initiation of the treatment (Figure 1C,D). The patient's symptoms were relieved and she was discharged in good condition. The bilateral abducens paralysis improved two weeks after discharge. The first diagnosis was communicant hydrocephalus due to tuberculosis meningitis. Subsequently, anti-tuberculosis medication was started.

Three months after discharge, the patient was re-admitted to our clinic with nausea, vomiting and headache. Physical examination was unremarkable. Cranial CT scan revealed slit ventricles, consistent with over-drainage of the ventricles (Figure 1E). The VP shunt was revised. The patient's symptoms relieved. On post-operative day 3 , the patient was discharged without any neurological deficits.

Three months after the shunt revision, the patient experienced nausea and vomiting again as well as neck pain and paresis in her right arm. Physical examination revealed global muscle wasting and increased deep tendon reflexes on the right arm. A craniocervical junction MRI revealed dural thickening starting from the craniocervical junction to the level of C4, particularly at the level of the tentorium cerebelli (Figure 2AE). This thickening was hypointense on $\mathrm{T} 1$-weigthed images and heterogeneously hyperintense on T2-weigted images. Axial MRI of the craniocervical location with gadolinium contrast agent showed diffuse leptomeningeal enhancement with a nodular lesion at the level of C1 (Figure 2D). There

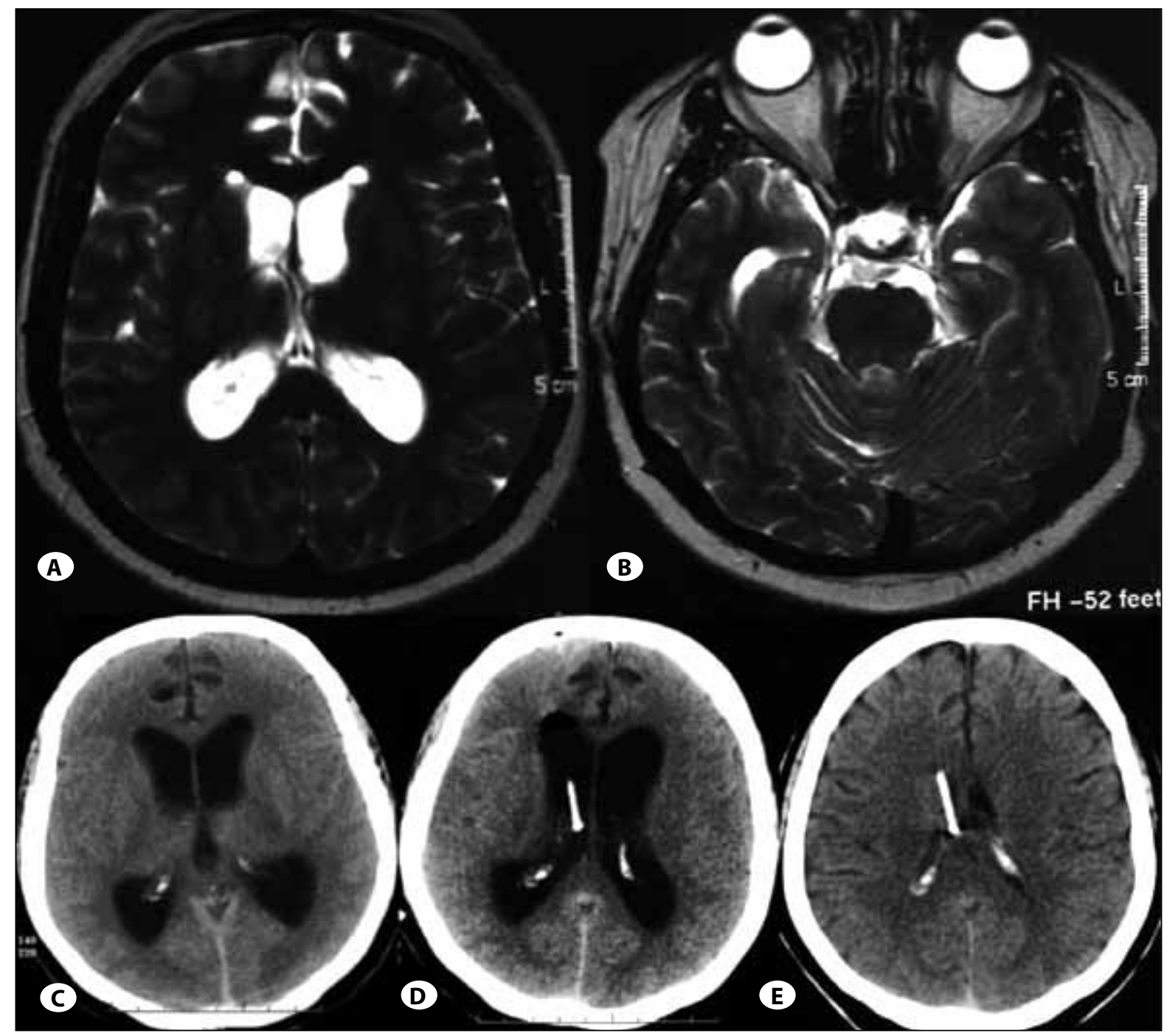

Figure 1: The T2-weighted MR image excluded hydrocephalus on the first admission (A-B). During her hospitalization, the ventricules began to dilate (C) and eventually a VP shunt system was inserted (D). The patient was admitted for her increased ICP symptoms several weeks after her first discharge (E). 
were no parenchymal lesions. A biopsy at the level of $\mathrm{C} 1$ was performed for the diagnosis.

\section{Microscopic Examination}

Histopathology of the lesion showed a neuroepithelial tumor infiltrating the leptomeninges with a pattern suggestive of astrocytoma. The neoplastic cells had ovoid nuclei, and the cytoplasm was eosinophilic with presence of fibrillary processes (Figure 3A). However, other parts of the tumor showed the typical appearance of oligodendroglioma with round uniform nuclei and clear cytoplasm. Microgemistocytes of the gliofibrillary oligodendrocytic type were observed. Moderate cellular atypia and mitotic activity were evident.
There was no vascular endothelial proliferation and no necrosis. The following immunostains were conducted, using the streptavidin-biotin peroxidase complex $(A B C)$ method in all: i) Glial Fibrillary Acidic Protein (GFAP) (clone GA-5, diluted 1:250; Neomarkers, CA), ii) S100 protein (clone 4C4.9, diluted 1:250; Neomarkers, CA), iii) Epithelial Membrane Antigen (EMA) (clone E29, diluted 1:20; Neomarkers, CA) and iv) Ki67 labeling index (clone MIB-1, ready to use ; Neomarkers, CA). A large percentage of tumor cells expressed glial fibrillary acidic protein (GFAP) (Figure 3B) and S100 (Figure 3C) in immunohistochemistry. The Ki67 labeling index was $10 \%$ at hot spots (Figure 3D).

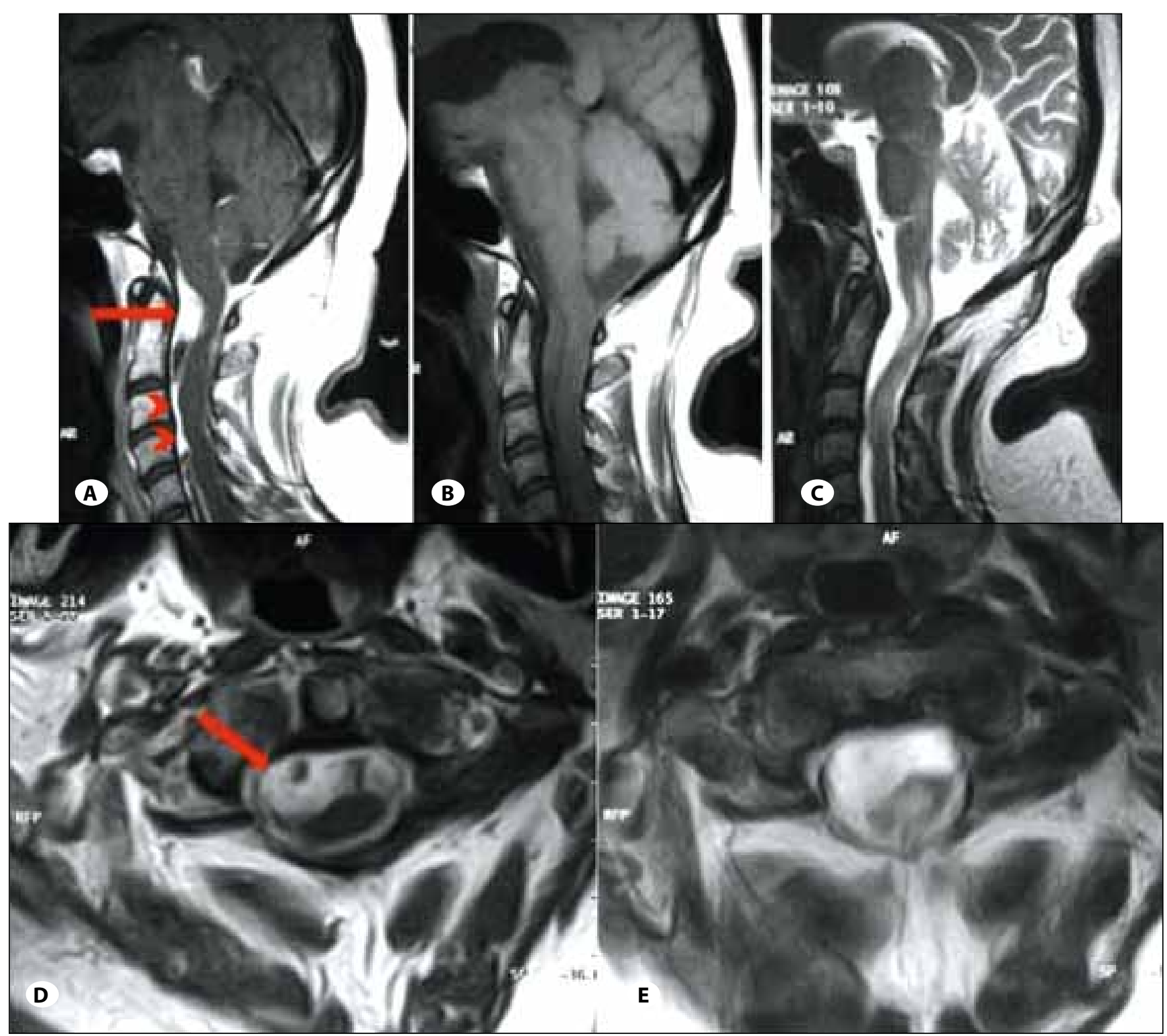

Figure 2: The MRI-scan of craniocervical junction with gadolinium contrast agent shows no sign of pathology consistent with presence of intracranial mass lesion (2A). Note that the dural thickening exhibits intense contrast material enhancement (2a, arrows), shows hypointensity on T1-weigthed images (B) and is heterogeneously hyperintense on T2-weigted images (C). The axial section of MRIscan with gadolinium contrast agent showing $\mathrm{C} 1$ level reveals diffuse leptomeningeal enhancement with a nodular lesion (D, arrow). T2-weighted axial section of MRI image shows hyperintensity anterior to the spinal cord (E). 


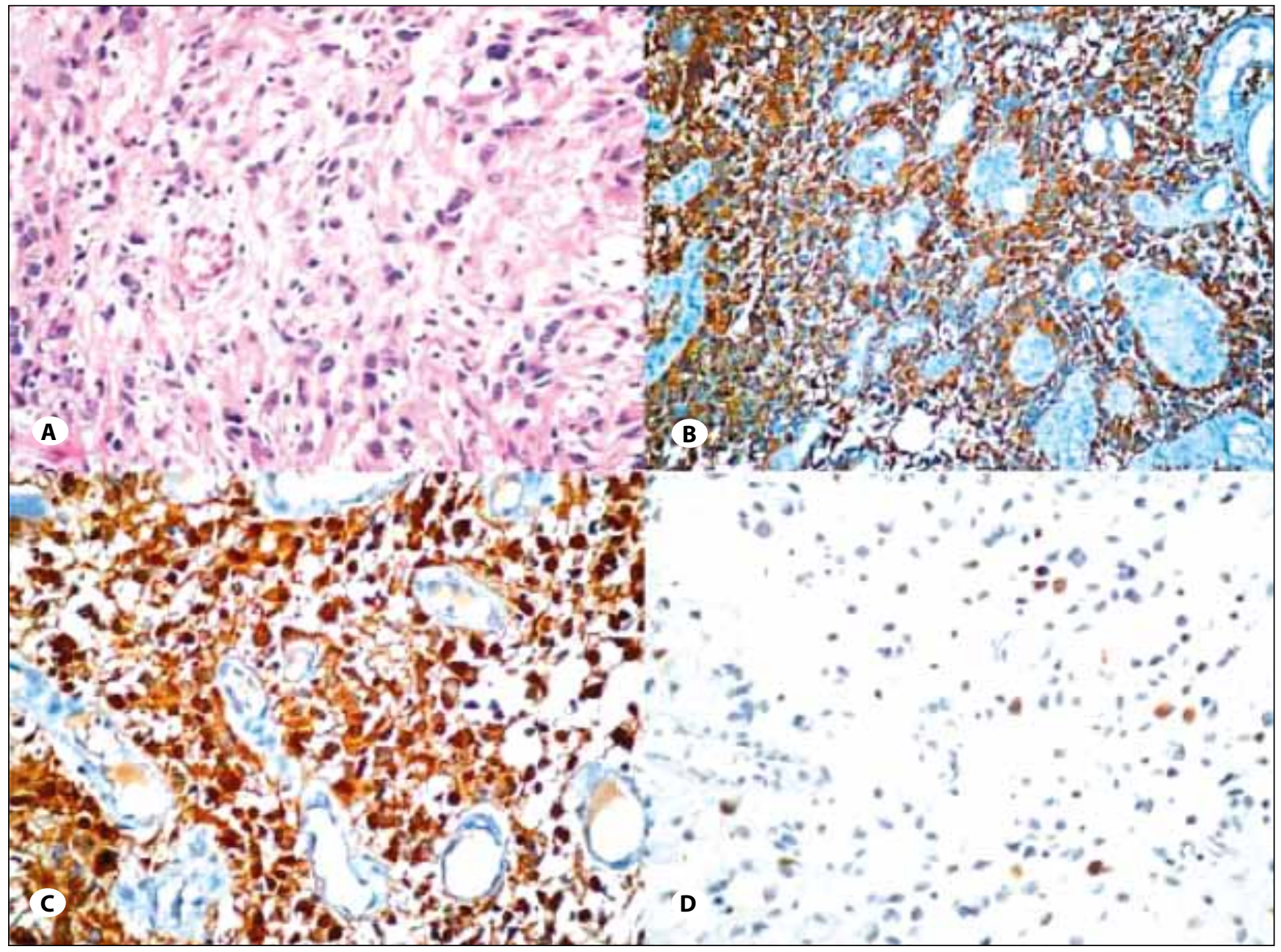

Figure 3: Astrocytes with severe atypical characteristics seen in high magnification (HE, x400) (A). Tumor cells with diffuse cytoplasmic GFAP reactivity (Neomarkers, GFAP, Streptavidin-biyotin, x400) (B). Tumor cells with diffuse cytoplasmic and nuclear S-100 reactivity. (Neomarkers, GFAP, Streptavidin-biyotin, x400) (C). MIB-1 index measured as 10\%. (Neomarkers, anti-Ki67, Streptavidin-biyotin, x400) (D).

Based on the histopathology and immunohistochemical results, this case was diagnosed as primary diffuse leptomeningeal gliomatosis, with phenotypic features of astrocytoma and oligodendroglioma (WHO grade III). .

\section{DISCUSSION}

PDLG is thought to originate from leptomeningeal heterotopic neuroglial nests, which have separated during the embryogenesis of the central nervous system $(3,13)$. Heterotopic glial nests occur in the subarachnoid space in about $1 \%$ of randomized necropsies, with a higher incidence $(25 \%)$ in patients with congenital malformations of the nervous system (1). These heterotopic neuroglial nests are mostly composed of astrocytic cells but may also include oligodendroglial component, and thus, primary diffuse leptomeningeal oligodendrogliomatosis cases have been reported $(6,14)$.

PDLG is a very rare and distinct central nervous system neoplasm occurring due to focal or diffuse infiltration of the leptomeninges without any intraparenchymal involvement by any kind of glioma or metastases $(1,3,4,7,14,15)$. PDLG usually appears as a contrast-enhancing lesion with thickening of the leptomeninges with imaging methods. $(2,4,10-12,14$, $15,17)$. Although non-enhancing or minimally enhancing leptomeningeal lesions in the cranium have been reported, they may be located in the spinal cord $(1,6,7)$. The disease may occur at any age group. It may also occur in the pediatric population (4). The clinical manifestations of the disease are quite variable. The most common presenting symptom is headache followed by vomiting, seizures, and neck stiffness $(1,4,5,7)$. The signs are also quite different including cranial nerve palsies, papilledema, altered level of consciousness, and those depending on spinal cord involvement $(1,2,4,8$, $9,16,18)$. CSF evaluation is usually consistent with elevated protein levels, absence of atypical cells in almost all cases. Low glucose levels and increased opening pressure in some cases may raise the suspicion of chronic meningitis. (1, 4, $7,14,18)$. Besides, CSF should be examined in terms of any 
microorganisms in order to rule out any type of bacterial or viral meningitis.

In this report, similar to the previously reported cases, a middle-aged woman with symptoms mimicking meningitis (neck pain, nausea, vomiting, and elevated CSF protein levels) has been presented. Neuroimaging methods indicated contrast enhancing leptomeningeal lesion predominantly involving spinal cord with a nodular lesion at the level of $\mathrm{C} 1$. As in other cases, empirical anti-tuberculosis therapy was initiated.

The histopathology findings in this case of neoplastic leptomeninges infiltration by a mixed tumor of astrocytoma and oligodendroglioma are unique. Most of the cases reported in the literature were astrocytomas $(1,7,11,12)$.

Despite the misleading clinical presentation, with findings suggestive of chronic meningitis and the absence of a parenchymal lesion, the diagnosis of PLDG must be considered. Cases with spinal cord involvement or cases without any contrast-enhancing lesions are especially challenging. However, the prognosis of PDLG is poor. The case presented here indicates that PDLG may exist with clinical symptoms mimicking those of chronic meningitis, and may histologically contain different phenotypic features.

\section{REFERENCES}

1. Baborie A, Dunn EM, Bridges LR, Bamford JM: Primary diffuse leptomeningeal gliomatosis predominantly affecting the spinal cord: case report and review of the literature. J Neurol Neurosurg Psychiatry 70:256-258, 2001

2. Bae JY, Choi BO, Sunwoo IN, Kim DI, Cho SH, Kim TS: Diffuse cerebrospinal gliomatosis with extensive leptomeningeal spread. Yonsei Med J 41:517-521, 2000

3. Cooper IS, Kernohan JW: Heterotopic glial nests in the subarachnoid space; histopathologic characteristics, mode of origin and relation to meningeal gliomas. J Neuropathol Exp Neurol 10:16-29, 1951

4. Debono B, Derrey S, Rabehenoina C, Proust F, Freger P, Laquerriere A: Primary diffuse multinodular leptomeningeal gliomatosis: Case report and review of the literature. Surg Neurol 65:273-282; discussion 282, 2006

5. Dietrich PY, Aapro MS, Rieder A, Pizzolato GP: Primary diffuse leptomeningeal gliomatosis (PDLG): A neoplastic cause of chronic meningitis. J Neurooncol 15:275-283, 1993
6. Gilmer-Hill HS, Ellis WG, Imbesi SG, Boggan JE: Spinal oligodendroglioma with gliomatosis in a child. Case report. J Neurosurg 92:109-113, 2000

7. Kastenbauer S, Danek A, Klein W, Yousry TA, Bise $K$, Reifenberger G, Pfister HW: Primary diffuse leptomeningeal gliomatosis: Unusual MRI with non-enhancing nodular lesions on the cerebellar surface and spinal leptomeningeal enhancement. J Neurol Neurosurg Psychiatry 69:385-388, 2000

8. Kitahara M, Katakura R, Wada T, Namiki T, Suzuki J: Diffuse form of primary leptomeningeal gliomatosis. Case report. J Neurosurg 63:283-287, 1985

9. Kobayashi M, Hara K, Nakatsukasa M, Murase I, Toya S: Primary spinal leptomeningeal gliomatosis presenting visual disturbance as the initial symptom: Case report. Acta Neurochir (Wien) 138:480-481, 1996

10. Leproux F, Melanson D, Mercier C, Michaud J, Ethier R: Leptomeningeal gliomatosis: MR findings. J Comput Assist Tomogr 17:317-320, 1993

11. Ng HK, Poon WS: Diffuse leptomeningeal gliomatosis with oligodendroglioma. Pathology 31:59-63, 1999

12. Pingi A, Trasimeni G, Di Biasi C, Gualdi G, Piazza G, Corsi F, Chiappetta F: Diffuse leptomeningeal gliomatosis with osteoblastic metastases and no evidence of intraaxial lesions. AJNR Am J Neuroradiol 16:1018-1020, 1995

13. Popoff N, Feigin I: Heterotopic central nervous tissue in subarachnoid space. Arch Pathol 78:533-539, 1964

14. Rees JH, Balakas N, Agathonikou A, Hain SF, Giovanonni G, Panayiotopoulos CP, Luxsuwong M, Revesz T: Primary diffuse leptomeningeal gliomatosis simulating tuberculous meningitis. J Neurol Neurosurg Psychiatry 70:120-122, 2001

15. Rogers LR, Estes ML, Rosenbloom SA, Harrold L: Primary leptomeningeal oligodendroglioma: Case report. Neurosurgery 36:166-168; discussion 169, 1995

16. Schmidbauer M, Muller C, Podreka I, Mamoli B, Sluga E, Deecke L: Diffuse cerebrospinal gliomatosis presenting as motor neuron disease for two years. J Neurol Neurosurg Psychiatry 52:275-278, 1989

17. Shin YM, Chang KH, Han MH, Myung NH, Chi JG, Cha SH, Han MC: Gliomatosis cerebri: Comparison of MR and CT features. AJR Am J Roentgenol 161:859-862, 1993

18. Tsui EY, Loo KT, Mok CK, Yuen MK, Cheung YK: Primary multifocal leptomeningeal gliomatosis. Eur J Radiol 37:5-7, 2001 